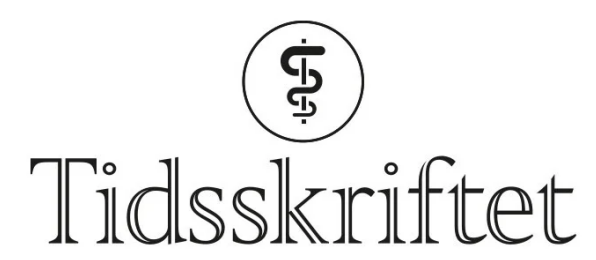

DEN NORSKE LEGEFORENING

\title{
Pytonolje er bra for musehjerter
}

\author{
NYHETER
}

TRINE B. HAUGEN

Email: trine.b.haugen@hf.hio.no

Tidsskriftet

\section{Fettsyrer i postprandialt plasma fra pytonslange fører til gunstig fysiologisk hjertehypertrofi i slanger og mus.}

De fleste pattedyrmodeller for adaptiv gunstig hjertehypertrofi viser en moderat hjertehypertrofi på 10-20\% etter flere uker med trening. Hos pytonslanger $\emptyset$ ker hjertemassen med 40 \% innen 2-3 dager etter et stort måltid. Nå har amerikanske forskere studert de molekylære mekanismene bak denne ekstreme veksten for å kunne anvende kunnskapen på mennesker (1).

Forskerne fant ut at økningen i hjertemasse ikke var et resultat av celleproliferasjon, men av cellehypertrofi med aktivering av fysiologiske signalveier. Pytonhjertet akkumulerte ikke triglyserider eller fettsyrer, til tross for høye nivåer av sirkulerende lipider etter måltidene. Derimot ble det påvist en betydelig aktivering av transport og oksidasjon av fettsyrer, kombinert med økt ekspresjon av det kardioprotektive enzymet superoksiddismutase. Forskerne påviste en kombinasjon av fettsyrer i postprandialt pytonplasma som stimulerte til vekst av hjertet etter injeksjon i pyton og mus.

- Dette er en vel gjennomført studie om adaptiv gunstig hjertehypertrofi, sier overlege Thomas von Lueder ved Hjertemedisinsk avdeling, Akershus universitetssykehus.Forskerne viste i at slangemodellen ble de samme "gunstige» vekststimulerende signalveier fulgt som i klassiske treningsmodeller. Hypertrofien er reversibel og forsterker hjertets pumpekraft.

At det ble identifisert spesifikke fettsyrer i postprandialt pytonplasma som formidlet hjertehypertrofien, er svært interessant, sier von Leuder. - En tilsvarende syntetisk fettsyreblanding ga samme gunstige hypertrofi når den ble injisert i mus eller fastende pyton. Neste skritt vil være å teste om patologisk hypertrofi og annen remodellering, f.eks. ved eksperimentell hypertensjon eller hjerteinfarkt, kan påvirkes av disse fettsyrene på en gunstig måte, sier von Lueder. 
LITTERATUR

1. Riquelme CA, Magida JA, Harrison BC et al. Fatty acids identified in the Burmese python promote beneficial cardiac growth. Science 2011;334: 528-31.

Publisert: 24. januar 2012. Tidsskr Nor Legeforen. DOI: 10.4045/tidsskr.11.1403

(C) Tidsskrift for Den norske legeforening 2023. Lastet ned fra tidsskriftet.no 26. april 2023. 